\title{
Control Systems in Hybrid Energy Renewable Power Systems: Reviews
}

\section{S M Wijewardana}

\begin{abstract}
During the past couple of decades extensive research has been conducted in renewable energy hybrid systems. As a result, wind solar hybrid energy systems have become more popular and limelight of sustainable energy research. At present, the technology in this area has been developing very rapidly in the manufacturing sector producing new equipment with many patent rights. The main aim of this review paper is to re-examine the application of control systems used in hybrid energy systems and opportunities for further research identified.
\end{abstract}

Keywords: Algorithms, Control, Fuel cells, Fuzzy logic, Hybrid energy systems, Optimization, Photovoltaic, Wind energy conversion.

\section{Introduction}

Adequate and affordable energy supply is a key for global development and reduction in poverty. Energy supply through the national grid in a form of electricity has been a major factor to decide one's quality of life. Noticeably, this requirement was made by consuming more depleting sources of fossil fuels. In return it caused not only the shortage of coal, oil, minerals and other energy resources, but also polluting the environment. The consequences are the gradual increase in global temperature annually in an alarming rate with a huge impact and danger to the livelihood of humans and animals on the planet [1].

The aim of this paper is to review and examine the current control systems and their future developments mainly in standalone hybrid energy systems (HES). Section-2 highlights the general overview of renewable energy and the structure of multi-energy hybrid power supply systems. The application of control systems, software packages and the optimization algorithms used in designs has been discussed under section-3. The section-4 briefly reexamines the application of control systems used in HES for research purposes. The conclusion is given in section- 5. Expansion of the market, future trends and grand challenges are given in section- 6 .

\section{Renewable Energy/Alternative Energy/Hybrid Energy}

Renewable Energy (RE) has always been in forefront and it is accepted that technological advancement in this area would expand for the implementation of the carbon footprint [2]. For centuries, biomass (wood) provided us with heating and cooking for our homes while steam engines, hydro plants and wind mills provided us the power for our industries and daily requirements as in [3],[4]. As at today, the technology in this area has been developing specially in the manufacturing sector producing new equipment with many patent rights. These technologies include power generation from wind turbines (WT), on-shore and off-shore wind farms, the evolution of the current electrical grid, using new technology to optimize the conservation and delivery of power (Smart Grid and Smart metering)[5],[6],[7],[8],[9]. In microelectronic manufacturing sector the introduction of multijunction solar photovoltaic (PV) cells has increased the efficiency of solar arrays from $20 \%$ to $43.5 \%$ [2]. Though, the intermittency is a problem for wind, wave and solar power;marine current energy has become one of the most exciting emerging forms of renewable energy. Unlike many other forms of renewable energy, marine currents produce consistent source of kinetic energy caused by regular tidal cycles influenced by the phases of the moon [10].

Island of Sri Lanka which is surrounded by the Indian Ocean can be blessed by tapping more and more renewable energy resources from offshore wind farms and from tidal farms. It is encouraging to note that these projects were initialised way back in 1999 with the installation of first wind turbine in Hambantota. According to the wind study

Eng. S M Wijewardana, B.Sc.Eng(Mech) (Moratuwa), M.Eng(EEE)(Victoria), PGDip. Digital Control(Victoria), PGDipEd (Victoria), C.Eng, MIE(Sri Lanka), PhD Student, Queen Mary University of London 
conducted by the National Renewable Energy Laboratory (NREL), USA, the estimated wind power energy that could be tapped is around 20,740 MWs [11].

Apparently these figures are only for the inshore wind farms around the specific coastal belts. Hence, the real figures could be very much higher than that of the NREL, US figures. According to the Ceylon Electricity Board and the Renewable Energy Authority websites from Sri Lanka, there are no offshore large scale wind farms and they are yet to be constructed. The largest inshore wind farm is at Seguwantivu, in Puttlam district managed by Seguwantivu and Vidatamunai (Pvt.)Ltd. These wind farms have 25 wind turbines in total and with a total capacity of $800 \mathrm{KW}$. They generate 20MW to the National Electricity Grid [12]. Penetration of the electricity supply from these WTs to the grid faces number of challenges; in particular, to ensure the power balance, security of safe maintenance, computer based remote control and automation systems development, in addition to reactive power, frequency, voltage variation, harmonics and phase lock loop control (PLL) [5],[7],[8],[9].

In addition to the wind turbine generators, discussed above, hybrid fuel cell (FC) motor vehicles have added a new dimension to the transportation industry in general. In future instead of gasoline refill stations commuters will have to turn to the hydrogen filling stations or none as hydrogen is produced by the inbuilt hybrid fuel cell-electrolyser units.

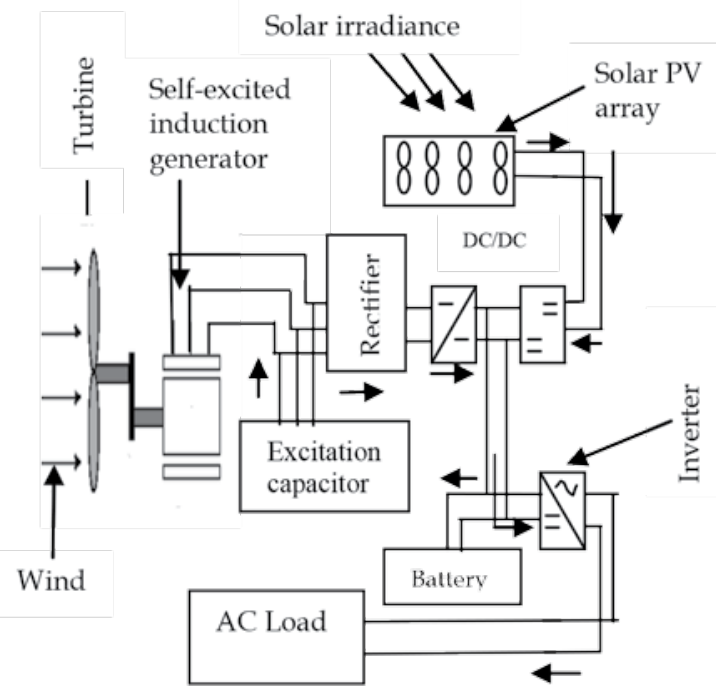

Figure 1 -Block diagram of a generic hybrid power supply system

Due to complementary nature of wind and solar energy it is now customary to use both systems together. However, when both sources cannot provide sufficient power when the demand is high, alternative back up sources like battery storage systems or capacitor banks provide energy for shorter durations until the wind and solar systems come back to normal operating conditions. Fig.1, shows a block diagram of a generic hybrid power supply system with a battery backup system.

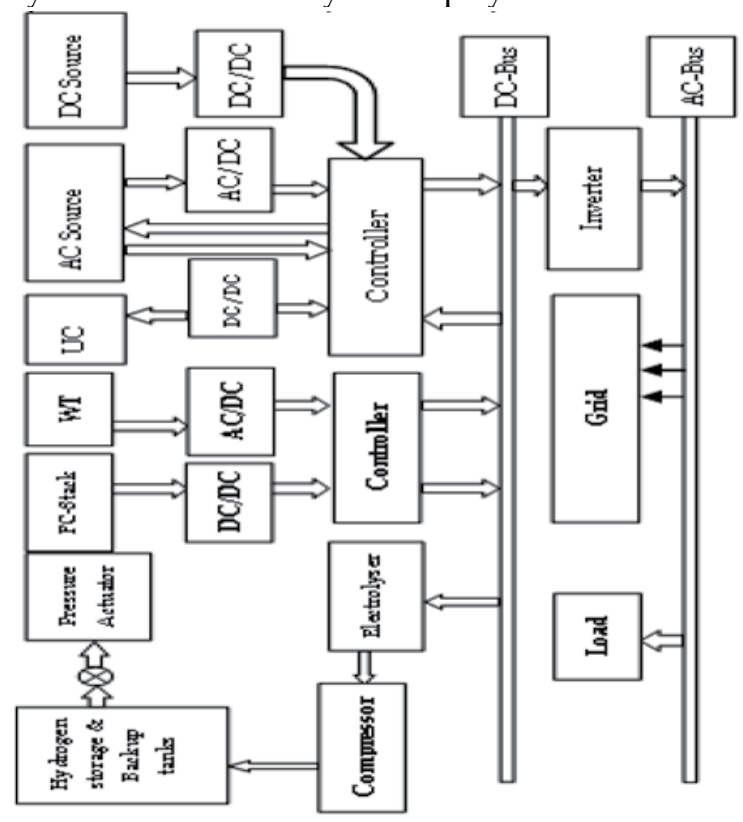

Figure 2 -Block diagram of a multi-energy hybrid power supply system

The block diagram shown in Fig. 2. is a multienergy hybrid power supply system that can be used to supply electricity to household customers as a standalone system. (UC: Ultracapacitor bank, FC: Fuel cells, WT: Wind turbine, Solar-PV: Solar photovoltaic)

The economic conditions and the availability of power sources can decide the topology and the number of power sources to be combined [13]. Excess power from the system can be fed into the grid for distribution or can be used to produce hydrogen gas for storage by using the electrolyser if proton exchange membrane fuel cells (PEMFC) are used in the plant[14].

\section{Control Systems in Hybrid Energy Systems}

Various control systems have been developed and presented by many researchers to use in hybrid energy systems (HES). Among them, as solar PV systems are occupying a large area due to low efficiency $(16-20 \%)$ [2], cost optimization with suitable maximum power point tracking(MPPT) systems have been utilised. Most researchers used the Perturb and 
Observe (P\&O) algorithm, Genetic Algorithm (GA) and Particle SwarmOptimization (PSO) algorithms for maximum photo voltaic power tracking (e.g.: pl. see: [15],[20]). Fuzzy logic(FL) and fuzzy based algorithms were used in [21],[22],[23],[24] and [25] for MPPT from solar PV arrays and to calculate the optimum wind turbine coefficient for maximum power output. However, control systems to tackle the variable nature of the wind energy, active and reactive power control, voltage variation, harmonics, frequency control are still being under investigation by researchers with the intention of succeeding low cost, maintenance free, frictionless drives as they have to be operated at very high altitudes and remote off-shore locations[8].

Proportional integral (PI) and proportional integral and derivative (PID) controllers have been used extensively by many researchers to control hybrid systems. Kabalci, E.;[15] proposed a system to use either a PI controller or an extended PI controller with an auxiliary controller programmed with the Perturb and Observe(P\&O) optimization algorithm. The output capacity of the wind turbine used in their system for modeling was $2 \mathrm{KW}$ permanent magnet synchronous generator(PMSG).PMSG was preferred as it does not require brushes or commutators and it does not have the problem of cogging torque and robustness. Doubly fed induction generators (DFIG) are normally used for higher capacities (Mega Watt range)[9]. These wind turbines are designed aerodynamically to suit variable wind speeds to achieve optimum efficiency by tracking the optimum tip-speed ratio. Therefore, the generator's rotor must be able to operate at a variable rotational speed. The DFIG system therefore operates in both sub- and supersynchronous modes with a rotor speed range around the synchronous speed. The stator circuit is directly connected to the grid while the rotor winding is connected via slip-rings to a three-phase converter. For variable-speed systems where the speed range requirements are small, for example $\pm 30 \%$ of synchronous speed, the DFIG offers adequate performance and is sufficient for the speed range required to exploit typical wind resources[9].

The MPPT system proposed by Kabalci, E. [15]was programmed by using $\mathrm{P} \& \mathrm{O}$ algorithm to extract energy from $170 \mathrm{~W}$ solar PV panels. Energy from the wind turbine through the PMSG was sent to the AC-DC conversion with an uncontrolled full-bridge rectifier. Converter outputs were then fed into a bus bar through an interface to transform into the three phase power supply. The system monitored the harmonics produced[15].

Chen etal.[16] used a PID controller to control the gas demand (hydrogen and air) to the fuel cell (FC) hybrid system. A novel control strategy was introduced by Haruni et al.[17] to control a hybrid system comprised with WT, rectifier, battery storage (BS) system, electrolyser, FC, load side inverter, voltage and frequency regulator. Same researchers then developed a standalone hybrid power system by using Solar-PV/FC/UC with a new power controller [18]. Uzunoglu's [19] system mainly relying on solar-PV array which feeds electricity to the electrolyser to produce hydrogen to store for future storage and also transfers electricity to the load. When the PV system cannot meet the load demand, FC system supplied electricity as a backup system. When FC also cannot completely satisfy the demand then the UC bank provided the electricity to the load. The key feature of the system was to introduce a MPPT system to extract optimum power from the solar-PV array by using the curve fitting technique algorithm in Matlab. The pulse width of the switching signal was determined using reference and measured voltage to represent the characteristic of the solar cell exponential equation. Then the pulse width command and the carrier signal were compared to obtain the switching of PWM signals. Other key feature of the research was that a main controller was used to control Solar$\mathrm{PV}$, hydrogen storage tank pressure, UC and the load.

Optimization study was carried out by Laidi, etal. [26] using a hybrid energy controller supplied by Torjan Battery company. The difference between this research and the [19] is that Laidi et al.[26] used Multi Objective Evolutionary Algorithm and the GA to find the best combination of components for optimization. Khan et al.[27] used two PID controllers to control the hydrogen and oxygen flow to the proton exchange membrane fuel cell (PEMFC). In addition, Khan et al. [27] presented the Laplace domain transfer functions to model the UC bank and wind turbine dynamics which is convenient to implement as a dynamic model in Simulink with the PID controllers.

Laplace domain dynamic transfer function for $\mathrm{UC}($ eq.1.) is given below:(Khan et al. [27])

$\frac{V_{\text {ucap }}}{V_{\text {stack }}}=\frac{s+1 / R_{C} C}{s\left(1+R_{S} / R_{C}\right)+1 / R_{C} C}$ 
The symbol $C$ is the capacitance and the $R_{C}$, and $R_{S}$ were defined as the series resistance and the stray resistance, $V_{\text {ucap }}$ and $V_{\text {stack }}$ are the input and output voltages of the UC system.

Weijun et al.[28] designed a dual closed loop control method to track the wind energy changes and stabilize the system. Inverter control system in this research acts as a main controller for the WT/Solar-PV and the BS system. Bhattacharya et al. [29], presented a hybrid power system consisting of WT and Solar-PV panels. The system used a central controller and the simulation results were used to validate the use of three solar panels. Jitendraet al.[30] presented a paper on modeling and simulation of Wind/Solar-PV hybrid system using Simulink. Modeling involved the voltage and frequency variation control, number of household connections and their power usage. Wang etal. [14] presented a research paper on WT/Solar-PV/FC system incorporating a MPPT controller for the SolarPV system, pitch angle controller and a power controller for the WTG. Ciobotaru et al. [26] presented a Solar-PV inverter control system which was programmed and tested by usingdSPACE software package. Also, Cibotaru et al.[26] included a MPPT system in addition to the Phase-Locked-Loop (PLL) DC voltage controller and a current controller. Fuzzy based $\mathrm{P} \& \mathrm{O}$ algorithm was used by Sankaganesh et al. [33] for MPPT of the solar-PV system. Standalone WT/Solar-PV hybrid system was presented by using HOMER software in the paper presented by Badawe et al.[33]. FuzzyPID controller to control a WT/solar-PV hybrid power system was presented by Fengge, et al. [34]. Fuzzy intelligent controller in[34] was used for the switching purposes and for charge control in the battery storage system. PID controller was used to control the pulse width modulation. Since, the control system presented by Fengge et al. [34] has a feedback loop for battery charging and state of charge(SOC) estimation, Fengge's controller is more preferable to use than, the Wang's [14] controller though it has a fuel cell back up system.

Optimal Fixed-Threshold Discharge Strategy and a Fuzzy Discharge Controller was used to control WT/Diesel-Generator/BS hybrid system in Kathirvel's [23] control system. Important aspect of this research was to connect the output power into $1 \mathrm{KW}$ Grid through three phase breaker switching system and a bus by monitoring the load voltage. Practical implementation results were not available for review at the time of writing. Baghaee et al.[35] published a research paper on designing a novel multi-objective optimization algorithm to minimize the objective functions. As the research was more directed towards cost optimization it will be discussed in a different article. Fuzzy logic controller was implemented by Mohammad et al. [36] by using HOMER software. Fuzzy logic controller directs the excess power of the hybrid system to BS system and then to the electrolyser for producing hydrogen gas for storage. Cost optimization, analysis, energy management, reliability studies were carried out by researchers in [24],[37],[38], [39],[40], [41], [42], $[43],[44],[45],[46],[47],[48],[49],[50],[51],[52],[53]$ etc. will not be discussed in detail as this paper highlights the control system applications to the stand alone HES. Eshita et al. [54]presented a multilevel inverter control system, diode rectifier and boost regulators to control the rotor three phase connection from the DFIG while the stator is directly connected to the grid. Inverter controller with a 3-level neutral point clamped (NPC) with 4 switches, antiparallel diodes and 2-diodes per phase were used to extract the maximum power from the WT. The system recorded low harmonics.

$I_{\mathrm{mp}}=0.9 I_{\mathrm{sC}}$

When many researchers used the Perturb and Observe (P\&O) algorithm, Genetic Algorithm (GA) and Particle Swarm Optimization (PSO) algorithms for maximum photovoltaic power tracking [15],[20], Eshita at al. [54] used equation (2) to compare the $I_{\mathrm{mp}}$, panel output current at maximum power point and $I_{\mathrm{SC}}$, short circuit current of PV panel (pl. see [54] for more details).

Sukamongkol, et al.[55] presented a battery charge controller to observe the SOC. Comprehensive review covering the areas of hybrid energy systems configuration, unit sizing, bus connection, control and energy management, future trend and challenges were given in the review paper presented by [56]. Other review papers presented were [57], [58],[59], [60],[61]. The review paper presented by Nema, P., et al. [60] was more descriptive in the areas of unit sizing, optimization and mathematical modeling, while in [61] cost optimizing, modeling and system selection was reviewed. Review paper submitted by [59] was focussed mainly on power management and optimization algorithms, and then paper[58] was extended towards the green building designs and energy performance of green buildings. Optimization methods, pros and cons, future research, on-going work were 
discussed in the review paper presented by [57].WT/Solar-PV/BS hybrid system was presented by Abdel-Salam et al. [63]. Newton Rapson method was used for the system sizing of WT, solar PV and the BS units.

Wavelet based load sharing and fuzzy logic based control algorithm was proposed by Erdinc, et al.[64]. Dynamic modeling of fuel cell control system, UC bank, fuzzy logic controller inference system, reference power tracker for the FC system were the key features of this research and the system was mainly designed for electric vehicles. PID controller with an ultrasonic sensor feedback loop was introduced by Delimustafic et al.[65]. A novel control strategy was presented by Uzunogh et al. [66]. DC/DC converters were designed for each Solar-PV, FC, and the UC banks. Main controller was used for the switching purposes and was operated by a decision algorithm. Fuzzy logic control system was proposed by Shia, et al. in [67] for the solar- PV and WT system. Hierarchical fuzzy controller algorithm was presented for controlling the loading and unloading of wind generator. $\mathrm{P} \& \mathrm{O}$ algorithm based fuzzy logic controller was presented by Safani et al. [68] while power management controller was introduced by Lalit et al. [69].Hybrid system modeling and simulation studies using LabView was presented by Aissa et al. [70]. Voltage controller for the wind turbine generator, MPPT system and a AC/DC converter with DC/DC converter configuration was presented by Nabil et al.[71] by using a PI controller for the inverter. Yuehua et al. [72] presented a MPPT system for the WG and for the Solar-PV system which was optimised by using $\mathrm{P} \& \mathrm{O}$ algorithm.

Neural network control strategy was used in LI-Jifang et al. [73] with the use of LevenbergMarquant algorithm. Multi-energy hybrid power supply controller is connected to all sub units of power sources including storage units, rectifiers, converters (DC/DC) and inverters. The neural network structure was constructed with input layer(five inputs), hidden layer(nnumber of hidden layers) and with an output layer (four outputs). Activation function used for all four neurons is Sigmoid function and the function used: $f(x)=1 /\left(1+e^{-x}\right)$. Learning rule used for the system was the back propagation algorithm until the desired outputs were reached. Initial weight calculations were performed by using the forward pass and activation function. The same configuration was applied to all three sources of WT, Solar PV and the energy storage unit. Another neural network based model for a hybrid energy system was presented by Lin et al. [74].Lin presented a fuzzy neural network (FNN) and a neural network (NN) to compare the simulations. NN model was similar to the one presented by[73]. However, the proposed FNN [74] is a general NN model with 3 layers and its fuzzylogic system that has singleton fuzzifier, product inference, and center-average defuzzifier. The difference between the two is that [74] used an intelligent controller with radial basis function network and improved Elman neural network (ENN) for MPPT.

Haruni, AMO., et al. [18] published a paper on Novel Operation and Control Strategy for a Standalone Hybrid Renewable Power System. The system designed was to operate under two levels. The top level controls the energy management and then regulates the power depending on the wind and load conditions. The second level was the load regulation when unfavourable wind and inadequate storage of power there to meet the requirement while avoiding system blackout. Proposed structure given was clearly presented with details and each stage had its own controller. Potamianakis, et al.[75] used an automatic voltage regulator (AVR) to keep the constant terminal voltage. Over excitation limiter (OEL) was used to protect the field winding of synchronous generator from unacceptable steady-state field current. Load tap(LT) changers have been used for bulk power delivery transformers and mechanically switched capacitors were used to keep the bus voltage and the power factor at a desired level. Unlike other PID, NN, Fuzzy Logic control systems discussed above, the proposed system in [75]which uses the switching systems,can be identified as a cost effective and easy to maintain control system. Onar, et al. [51] used a main controller (similar to a main controller concept as shown by Fig.3 later in this paper), for their proposed Wind Turbine/SolarPV/PEMFC/UC hybrid power system. Overall system configuration was given as a block diagrams, in which the main controller was used to control the output power of Solar-PV, WT, FC and the UC bank. Depending on the power demand of the microgrid in the neighbourhood, main controller can decide which source is reacting to meet the demand. Toextract the maximum power output from PEMFC, Solar-PV system and the wind generator, the Genetic algorithm was used. Setiawan, et al. [36] used a PID controller to control a motor/pump which is pumping 
water from a pre-treatment chamber to a desalination plant as described in the research paper.

Liang, W., and Littler, T., [77] published a research article on modal extraction for wind turbines using moving window subspace. The method developed was for wind turbine model identification using the Multivariable Output Error State-Space (MOESP) identification algorithm. It was further modified into a fast moving window QR decomposition (QR factorization: $Q$ and $R$ are matrices) and propagator method from array signal processing, yielding a moving window subspace identification algorithm. Initially the algorithm assumed the order of the system. For the purpose of extracting modal information the turbine was modelled as a Linear Parameter Varying (LPV) system. The non-linear system was approximated as a piecewise time invariant system in consecutive data windows. Numerical simulations show that the moving window algorithm can track the model information. The method identifies as low computational burden compared to conventional batch subspace identification. It is interesting to note that Liang's [77] presentation has not so far validated or tested by Block Lanczos or by PowerDynamics. Supervisory controller was introduced by Kalantar, et al.[21] to capture maximum energy from WT/Solar-PV hybrid system. It is an adaptive feedback linearization controller that calculates the reference powers for the battery regulator controller, microturbine controller, and dump load controller based on subtraction of load power from sum of WT and PV array powers. In order to compare the operation of the adaptive controller, fuzzy and a PID controllers were used. The simulation results for 50s (50 was selected for ease the calculation for fuzzy controller) proved that Lyapunov adaptive controller performed better than the Fuzzy and PID. The standard of the research work, state of the art applications are highly commendable and overall, it was a very good research paper in this context. Qi, W., et al.[78] introduced a supervisory predictive control system for the standalone Wind/Solar-PV hybrid system. It was a supervisory model predictive control (MPC) system for the optimal management and operation of hybrid standalone system. The method computes a power reference for the wind and solar generators at each sampling time while minimizing a suitable cost function. The power references were then sent to two controllers which drive wind turbine generator or Solar-PV arrays. Runge-Kutta numerical integration method was used for simulations. Huang, etal.[79] published a research paper on WT/Solar-PV hybrid system. $\mathrm{Hu}$ and et al.[79] used the MPPT control method by using the principle of variable step Perturbation Algorithm. Simulink had used to verify the system suitability. Hybrid systems use many tracking methods to find the maximum power point to operate: fixed voltage tracking method, power feedback method, disturbance observer method are some of them. The proposed method employs the controlling total output power of wind and Solar-PV to track the each source's maximum power.

Qi, Y.,et al. [80]also proposed a high efficient mode optimal control method for the Wind/Solar-PV/BS system. Generation scheduling curve of the hybrid system and minimum charge-discharge times of the battery have been taken as objective functions. SOC of the battery and the charge rate of the active power have been taken as constraints. Overload state of the battery was monitored by output energy and by the current. The system was validated by using Simulink. Three levels of control procedures and working according to the power regulation plan of each station was noticeable in the design. Energy management of Wind/Solar-PV/BS hybrid system with a consideration of memory effect in battery was presented by Mousavi, et al. [80]. Each subsystem of wind generation, Solar-PV array and the battery system was modeled using Matlab. Then the system was controlled by a charge controller by remembering the wind and solar energy output given at any instant to the charge controller. Linear short term prediction method was employed within the controller with wind and solar energy available at any instant to gain cost optimization to the system. It was recorded that PSO algorithm and the fuzzy control method have led the battery charge and discharge more reliable and cost effective. But none of the experimental details were available for reference at the time of review.

Meenakshi, et al.[81] published a research article on an intelligent controller for a Standalone hybrid energy system. The system comprised with a standalone wind driven selfexcited induction generator (SEIG), Solar-PV array, DC/DC converter, battery bank, DC/AC inverter, $\mathrm{AC} / \mathrm{DC}$ rectifier to the induction generator. Neuro-controller was used to track the maximum power points of the wind and solar arrays. Matlab/Simulink has been used to 
study the dynamic model. The neuro controller was trained with 150 simulations data using Back Propagation Algorithm. The Outputs of the controller are the duty ratios of the chopper and firing angle of the controlled rectifier.

Delimustafic, et al.[82] introduced a control system to monitor the water level of a storage tank system. The tank water level control was achieved by a PI and a PID controller. Effective energy distribution and a reliable power supply were achieved by using switched logic architecture. Their research also included the analysis of power converters using parameters generated by simulations results. Use of a GUI for data monitoring, control and supervision within the SCADA system was a key feature in this research. PowerSim software was used to model and simulate the AC/DC converter and the DC/ AC converter.

Mtshali, et al.[83] published a paper on Simulation and modelling of WT/Solar-PV/BS hybrid standalone power system. Novel controller was designed to supply load power at least from one source.

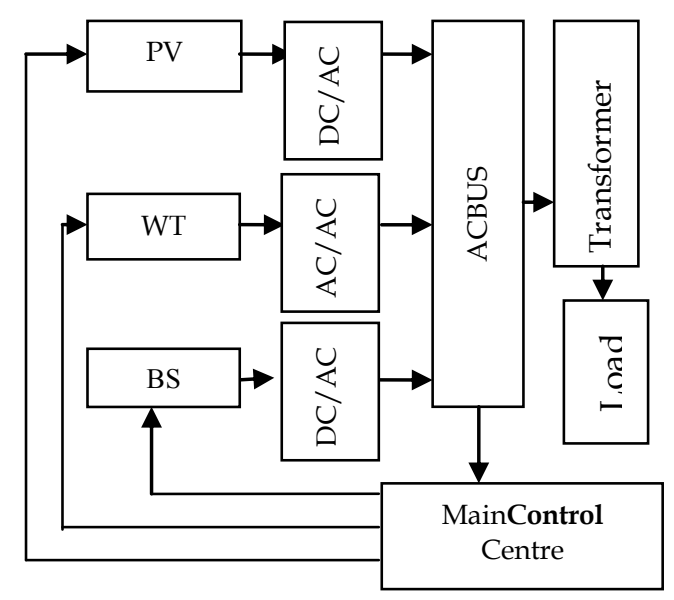

Figure 3 -Main control centre to control a hybrid energy system.

Patsios, C., et al.[84] presented a paper on control and analysis of hybrid renewable energy-based power system. Proposed system was a WG/Solar-PV/FC hybrid energy system and the FC was there to supply power when the WG and Solar-PV systems cannot meet the demand. UC bank was included in order to withstand rapid power fluctuations in the system when the power demand and supply changes very rapidly. The simplicity and the neat presentation of the paper was very commendable and the mathematical modeling is very clear and explicit. Liu, X., et al.[85] published a research paper on a hybrid AC/DC Micro-Grid. The designed system included a wind turbine with a doubly fed induction generator (DFIG), diesel generator, UC bank and a Solar-PV array. Coordination control algorithms were proposed to balance the power flow between AC and DC grids and to maintain both DC and AC voltages. Mathematical models for the Battery storage system, PV array, WG, Boost converter were given in the work with control system block diagrams.

Research article presented by Wandhare, et al.[53]introduced a control system to reduce the effect of intermittent solar radiation and wind velocity in hybrid Wind/Solar-PV system without losing MPPT. Researchers proposed a power conditioning unit to control the output power from the WT/Solar-PV system to eliminate the disturbances and supply constant output when both wind and Solar-PV supplies change randomly and unexpectedly. The design incorporated a high energy capacity UC bank to overcome this situation. The introduced control system did not affect the MPPT system associated with each source. The control strategy used was an inner fast current loop and an outer slow voltage correcting loop for both the grid side voltage source inverter (VSI) and for the UC converter. The researchers elaborated that the proposed system minimized the disturbances of the input current loops of VSI control and it does not introduce any harmonics in the system.

Important research article was published in modeling and analysis of emulator for distributed generation sources smart grid using digital signal controller by Andrew, XRI., et al. [86]. Scope of this research was to design a dynamic modeling system to various components of a standalone hybrid system and present the simulation results. In addition they proposed a centralised digital signal controller (DSC) to introduce to the system when many renewable sources are providing energy to the grid. The TMS320F28335 digital Signal Controller was used to program the system.

Gupta, SC., et al.[52] presented a research article on optimal sizing of a Wind/Solar-PV hybrid system. The paper presented a computational model for optimal sizing of the WT/Solar -PV hybrid systems. Loss of power supply probability (LPSP) index, total life cycle(TLC) cost have been used as indices for evaluation of different topologies of the hybrid system. Matlab energy balance calculation method was used to verify and validate the system. 
Kolhe, et al.[87] presented HES by using the software package TELELAB. The system comprised with a WT/Solar-PV array, and a battery storage system. Remote monitoring and a control system with necessary data interfaces were proposed in this paper. Data recording and monitoring was done through a data logger. The proposed system can operate remotely through internet connections and the system behaviour can also be monitored from remote locations. PLCs, data loggers, sensors and cameras were part of the system for data input and monitoring.

Jahdi et al.[88] presented a research article on renewable hybrid Grid-Connection using converter interfaces. The proposed research explored the connection considerations of wind Solar-PV hybrid systems to the grid. While many researchers used Simulink, HOMER and ETAB software packages were used by Jahdi et al. [88] for the simulation studies. The research also pointed out the practical problems they faced when it was connected to the grid. Distributed generation (DG) causes harmonics into the system and reduce short circuit impedances. During power failures DG systems function as independent power supply units and hence, causes dangers to the repairmen. Within the network with the current traversing back and forth, can cause voltage variations which can increase appreciably as opposed to the case where normally current is flown in one direction only from high to low. Remedial actions were also discussed in the research.

It has been observed that general strategy used for controlling HE systems have been categorised into centralized, distributed, and hybrid control paradigms. Noticeably, in all three cases, each energy source has its own local controller except in a few research publications, which decides the point of operation depending on the environmental conditions or according to the statistical data or loss of load probability (LOLP). Functionality of the centralised controller is to control each local controller. This type of controller can fail quickly (single point failure) as it has to get and send lot of information at once from local controllers for decision making. The distributed control paradigm (method) seems to have overcome the single-point failure, as the controllers made to communicate each other and come to a global compromised decision. These systems use intelligent algorithms, fuzzy logic, neural networks, optimization genetic algorithms or their hybrid combinations.
Hybrid centralised and distributed control paradigm strangely uses two or more centralised controllers to communicate the local controllers of each source. However, out of many control methods discussed so far, it is understood that the best control method is to use an intelligent, fast, economical centralised and local controllers. Literature review noted that though the wind energy systems are rapidly expanding still not economical compared to fossil fuel power supply systems. The grand challenges are for fool proof smart operation of the grid, use of low cost digital smart metering not vulnerable to software hackers, data protection of the consumers. In general, it was noted that the control and power management is easier when these RE systems operate at individual basis as micro grids than connecting to the main grid. The way forward is to tackle the technological problems to penetrate the RE power supply systems to the grid and the research alone cannot overcome these challenges/barriers unless governments spearhead to subsidise wherever possible to reach the renewable portfolio standards by 2030 and by 2050 .

\section{Re-examine the Application of Control Systems Used in Hybrid Energy Systems.}

Integration of large onshore and off shore wind farms to the national grid have created several technical challenges as discussed above. The technical challenges faced today are, grid code, smart grid power supply systems, pitch control, generator side and the grid side control for voltage stabilization, harmonics, frequency control, reactive power control and safe operation.

The literature shows that the majority of commercially available wind turbine generators are directly driven and directly connected to the grid. The future trend is also towards the direct drive grid connected wind turbine generations. Though the cost of the power electronic converters is getting cheaper, the system reliability will increase by eliminating the gear boxes and the power electronic converters. Also the system efficiency will increase because of the losses in the gear boxes and the power electronic converters are eliminated. Permanent magnet synchronous generator(PMSG), field excited synchronous generator (FESG) and the induction generator(IG) are three candidates for such applications. As permanent magnet excitation eliminates the excitation losses, PMSG are 
promising candidates for the electricity generation. The direct drive, grid connected induction generators and PMSG are intended for fixed speed operations. When the PMSG generator is connected to the grid, the speed is determined by the grid frequency and is constant. When the torque to the generator is increased (sudden blow of wind), the generator will produce electromagnetic force to resist an increase the speed. Sudden blow of wind can exert large stresses on the wind turbine's drive train. However, IG allows a small change of speed with the change of torque transferring to the generator and lower stresses and wear and tear of the drive train. As the IG and the PMSG machines have similar stators, the cost difference is mainly due to the rotor. As the cost of the magnetic materials is higher than that of aluminium, induction generator is cheaper than the PMSG for the same power rating. But, PMSGs have higher efficiency compared to IGs.

DFIG are popular as they can be directly connected to the grid. However, DFIGs have wound rotor IG where the stator directly connected to the grid and the rotor via slip rings is connected to the grid through a power converter mostly with a 4 quadrant $\mathrm{AC}$ to $\mathrm{AC}$ converters. Still, as the generator has to be connected to the turbine with a gear box it is always susceptible to the mechanical efficiency loss. Therefore, PMIG is viable as it has high efficiency compared to other types (No gear box).It has an advantage over electrically excited synchronous generator that does not require extra DC source for rotor excitation. But, as the size of the wind turbine increases the size of the magnets also increases. Therefore, the PMIG are much suitable for KW range wind turbine generators and the DFIG are suitable for MW range wind turbine generators and large scale wind farms[157].Research areas open in this context can be the application of fuzzy controllers and neural networks for system identifications. Fuzzy-PID controllers perform accurately reducing the cost of the hybrid systems as stand-alone units. Though some researchers proposed the neural network models, sliding mode control and Lyapunov functions with the Kalman Filters. They are very much suitable to apply in the aerospace industry with observable, uncontrollable systems. For hybrid energy systems, they are still at the experimental stage and yet to be assessed with the economic viability. Critical analysis of control systems associated with the wind turbine generators: DFIG, PMIG, switched reluctance generators and their performance comparison, controllers' stability are very specific areas that have to be addressed in a in a different perspective than in a review paper. This also includes the modeling and simulation studies of distribution networks analysis of smart grid, consumer connections, grid control and load balances.

\section{Conclusion}

Stand- alone hybrid systems with minimum of two energy resources are more suitable to supply electricity in remote areas to off-grid applications. This paper focussed mainly on the control aspect of standalone hybrid systems. As a result of the review, it was found that WT/Solar PV/BS systems are very popular. For stand-alone applications fuel cells combined with wind turbines have the drawback of low efficiency due to electricity-hydrogen-electricity conversion process and the FCs are used only as backup systems similar to BS systems. But, WT/FC systems economically perform better than the WT/BS systems. To achieve the best combinations of components sizing, most researchers used multi-objective evolutionary algorithm (MOEA), Genetic Algorithm and the Partical Swarm Optimization (PSO) techniques. However, considering the cost and computational time, researchers still prefer to apply Fuzzy-PID controllers in many hybrid control systems.

\section{Future Trend and Grand Challenges in Hybrid Energy Research}

The future trend is towards the construction of independent power plants with the use of wind turbines and hydrogen fuel cells. Within the next 5 years the technology and the commercialization in this area will be massive and Germany has already started establishing green energy power supply plants [102]. Commercialization has been restricted as expensive platinum was needed to make the catalyst, and Association of Fuel Cell Manufacturers is now developing low-cost ceramic minerals to overcome the problem. The application of artificial intelligent systems and a single controller to control the system than modular control systems are the way forward in this area.

Use of magnetic levitation concept in automobile industry and construction of magnetic super-fast highways to replace the motorways can be within the reach during the 
next 40-60 years (author's prediction). Application of magnetic suspension, gearless transmission and magnetic bearings for high capacity offshore wind generators is also a promising area for further research.

Future vision in this context has been prognostic on DC distribution systems and to develop more household appliances that run on DC power and complete rewiring of houses to accommodate DC power supply systems.

\section{References}

[1] Takle, E., “AgGM News Letter," Professor of Atmospheric science and professor of Agricultural Meteorology, Iowa St.University.gstakle@iastate.edu, March 2008.

[2] Wiedmann, T., Minx, J., \& Pertsova, C. C., "A Definition of Carbon Footprint in Ecological Economics Research Trends:" Chapter-1, pp. 1-11, Nova Science Publishers, Hauppauge NY, USA. 2008.

[3] Schulz, M., European Parliament, The President: "Directive 2013/14/eu of the European Parliament and of the council" Official Journal of the European Union[Online], http://eur-lex. europa.eu/, Visited,12 ${ }^{\text {th }}$ May 2013.

[4] European commission Brussels, (2011, January) “SEC(2011) 130 final: Commission staff working document: Review of European and national financing of renewable energy in accordance with Article 23(7) of directive 2009/28/EC, accompanying document to the communication from the commission to the European Parliament and Council Renewable. Renewable Energy: Progressing towards the 2020 target", http://www.epure.org/, Visited, 14th May 2013.

[5] Ekanayake, J., Liyanage, K., Wu, J., Yokoyama, A., \& Jenkins, N., "The Smart Grid", Published Online: 22 FEB 2012, 9781119968696.ch1.

\section{[6] Qiang Sun, Jianzhong Wu, Yibin Zhang ;}

Jenkins, N., Ekanayake, J. "Comparison of the development of Smart Grids in China and the United Kingdom “Innovative Smart Grid Technologies Conference Europe, 2010 IEEE.

[7] Samarakoon, K., Ekanayake, J., Jenkins, N. "Smart Grid", Investigation of Domestic Load Control to Provide Primary Frequency Response Using Smart Meters IEEE, Trans. On Volume: 3 Issue: 1, 2012 , pp.282 - 292.

[8] Arulampalam, A., Ramtharan, G., Jenkins, N., Ramachandaramurthy, V. K., Ekanayake, J. B., Strbac, G., “Trends in wind power technology. and grid code requirements" International Conference on Industrial and Information Systems, 2007. ICIIS 2007, pp. 129 - 134.

[9] Tennakoon, A. P., Arulampalam, A., Leite, H., Ekanayake, J. B., Abeyratna, S. G., “Operations of DFIG with simplified rotor current reference model and solution to the recent grid code requirements" Industrial Electronics, 2009.IEEE CON '09, pp. 3993 3997.

[10] www.marineturbines.com/tidal-energy, Visited, 28 ${ }^{\text {th }}$ sept 2014.

[11] http://www.windpower.lk/,"Importance of wind power", Visited, 29th Sept 2014.

[12] "Renewable Energy Resources in Sri Lanka" Online available on: http://www.energy. gov.lk/sub_pgs /energy_renewable_intro _resources.html,Visited, 29th Sept 2014.

[13] Bauer, P., Weldemariam, L. E., \& Raijen, E., “Stand-alone Microgrids.” IEEE, 2011.

[14] Wang, C., Nehrir, M. H., "Power management of stand-alone wind/photovoltaic/fuel cell energy system." IEEE transactions on energy conversion, Sept., 2008, Vol 23 No 3.

[15] Kabalci, E., "Design and analysis of hybrid renewable energy plant with solar and wind power." Energy Conversion and Management, Vol. 72,Aug. 2013, pp. 51-59.

[16] Chen, H. C., Qiu, J. C., \& C. H., Liu, "Dynamic modelling and simulation of renewable energy based hybrid power systems," DRPY April2008 Nanjing China.

[17] Haruni, A., Negnevitsky, M., Haque, H. E., Gargoom, A., "A novel power management control strategy for a renewable stand-alone power system" Power and Energy Society General Meeting, IEEE 2012.

[18] Haruni, A. M. O., Negnevitsky, M., “A novel operation and control strategy for a standalone hybrid renewable power system." IEEE transactions on sustainable energy, vol. 4 No2 April 2013.

[19] Uzunoglu, M., Onar, O. C., \& Alam, M. S., "Modeling, control and simulation of a PV/FC/UC based hybrid power generation system for standalone applications." Renewable Energy, Vol. 34, No. 3, March, 2009, pp.509-520.

[20] Ding, F., Loparo, K. A., Wang, C., "Modeling and simulation of Grid-connected hybrid AC/DC microgrid.", [Online], http:// ieeexplore.ieee.org/stamp/stamp.jsp?

arnumber=06343969,e-mail: fei.ding@case.edu.IEEE 2012. 
[21] Kalantar, M., Mousavi, G. S. M., “Dynamic behaviour of a stand-alone hybrid power generation system of wind turbine, microturbine, solar array and battery storage." Applied Energy, Vol. 87, No.10, Oct., 2010, pp. 3051-3064.

[22] Zhang, F., et.al. "Simulation research on wind solar hybrid power system based on Fuzzy-PID control." International Conference on Electrical Machines and Systems, October, 2007, Seoul.

[23] Kathirvel, C., Porkumaran, K., “Analysis and design of hybrid Wind/Diesel system with energy storage for rural application." IEEE (2010), pp.250-255.

[24] Yasin, A., Napoli, G., et.al. "Fuzzy logic based management of a stand-Alone hybrid generator." IEEE, 2011, pp. 690-696.

[25] Wang, Yi., Wu, J., et.al “Wind/Photovoltaic Hybrid Power generation based on fuzzy control." IPEMC. 2009: IEEE. 2284-2287.

[26] Laidi, M., Hanini, S., Abbad, B., et. al, “ Study of a solar PV-Wind-Battery hybrid power system for remotely located region in Southern Algerian Sahara case of refrigeration," Journal of Technology Innovations in Renewable Energy-1, 2012, pp 30-38.

[27] Khan, M. J., and Iqbal, M. T., "Dynamic modelling and simulation of a small wind-fuel cell hybrid energy system." Elsevier Renewable Energy, Vol. 30, Mar. 2004, pp.421-439.

[28] Weijun, Yu., Qian, X., “Design of 3KW wind and solar independent power supply system for 3G base station." Second International Symposium on Knowledge Acquisition and Modeling 2009.

[29] Bhattacharyya, D., Roy, R. C., “Hybrid energy system simulation for sustainable energy utilization." International Journal of Engineering and Advanced Engineering, Vol.3 Special Issue, ICERTSD, Feb. 2013, pp.622-627.

[30] Jitendra, K., Ankit, C., and Kumar, J. M., "Modeling and Simulation of Wind-PV Hybrid Power System using Matlab/Simulink", IEEE Students' Conference on Electrical, Electronics and Computer Science. 2012.

[31] Ciobotaru, M., et al. "PV inverter simulation using MATLAB/Simulink graphical environment and PLECS blockset." 2006 IEEE.

[32] Sankarganesh, R., Thangavel, S., "Maximum power point tracking in PV system using intelligence based $\mathrm{P} \& \mathrm{O}$ technique and hybrid Cuk converter." International Conference on Emerging Trends in Science, Engineering and Technology, IEEE, (2012), pp. 429-436.
[33] Badawe, M. El., Iqbal, T., Mann, G. K. I., "Optimization and modelling of stand-alone Wind/PV Hybrid energy system." 2012, 25 Canadian Conference on Electrical and Comp. Eng. (CCECE) IEEE, 2012.

[34] Fengge, Z., F., Shi, Q., et. al. "Simulation Research on wind solar hybrid power system based on Fuzzy-PID control." Proceeding of International Conference on Electrical Machines and Systems, 2007, Oct. 8-11, Seoul Korea, 2007, pp. 338-342.

[35] Baghee, H. R., Gharehpetian, G. B., \& Kaviani, A. K., "Three dimensional Pareto optimal solution to design a hybrid stand-alone Wind/PV generation system with Hydrogen energy storage using Multi-Objective particle Swarm optimization." 2012 Second Iranian Conference on Renewable energy and distributed generation. 2012.

[36] Mohammad, A., Gao, D. W., "Modeling and analysis of Wind/PV/Fuel Cell Hybrid Power System in HOMER." IEEE, 2007, pp.1594-1599.

[37] Ai, B., Yang, H., Shen, H., \& Liao, X., "Computer-aided design of $\mathrm{PV} /$ Wind Hybrid system." Renewable Energy, Vol.28, No.10, Aug. 2003, pp.1491-1512.

[38] Mohammadi, M., Hosseiniah, S. H., Gharehpetian, G. B., "Optimization of hybrid solar energy sources/wind turbine systems integrated to utility grids as microgrid (MG) under pool/bilateral/hybrid electricity market using PSO." Solar Energy, Vol. 86, No.1, Jan., 2011, pp. 112-125.

[39] Kaviani, A. K., Riahy, G. H., \& Kouhsari, S., "Optimal design of reliable hydrogen-based standalone wind/PV generating system, considering components outages." Elsevier Renewable Energy, Vol. 34, Nov., 2009, pp. 2380-2390.

[40] Ahmed, N. A., Al-Othman, A. K., et.al, "Development of an efficient utility interactive combined wind/photovoltaic/fuel cell power system with MPPT and DC bus voltage regulation." Electric Power Systems Research, Vol. 81, No. 5, May 2011, pp.1096-1106.

[41] Nandi, S. K., Ghosh, G. M., "Prospect of Wind-PV-Battery hybrid power systems as an Alternative to grid extension in Bangladesh." Elsevier Energy, Vo. 35(2010), pp. 3040-3047.

[42] Nandi, S. K., Ghosh, H. R., "A Wind-PVBattery power system at Sitakunda in Bangladesh." Elsevier Energy Policy, Vol. 37. No.9, Sep., 2009, pp. 3659-3664.

[43] Rahman, S. A., Zhang, N., \& J. Zhu, "Modeling and simulation of an energy management system for plug-in hybrid electric vehicles." Australian Universities Power Engineering Conference(AUSPEC 2008). 
[44] Daud, A. K., M. Ismail, M., et.al. "Simulation of hybrid power system considering of wind turbine, PV, storage battery and diesel generator: design, optimization and economical evaluation." International Journal of Energy Engineering, IJEE Vol.1 No.1, (2011), pp.56-61.

[45] Gupta, A., Saini, R. P. \& Sharma, M. P. "Hybrid energy system sizing incorporating battery storage: an analysis via simulation calculation." 2009 Third International Conference on Power systems, Kharagpur, India, Dec.2009,pp. 27-29. IEEE.

[46] Reddy, J. B., Reddy, D. N., "Probabilistic performance assessment of roof top wind, solar photovoltaic hybrid energy system." IEEE, 2004, pp.654-658.

[47] Al-Badi, A. H., Al-Toobi, M., et. Al, "Techno-Economic analysis for a hybrid stand-alone power generation." IEEE, 2011.

[48] Mougharbel, I., Z. Shehab, Z., \& Georges, S., "Simulation of a hybrid renewable energy system in rural regions." IEEE, 2012, pp.1150-1154.

[49] Pradhan, N., Karki, N. R., "Probabilistic reliability evaluation of Off-grid small hybrid Solar PV-Wind Power system for the rural electrification in Nepal." IEEE. 2012.

[50] Belfkira, R., Barakat, G., et. al. "Design study and optimization of a grid independent Wind/PV/Diesel system." Universite Saint Joseph, Faculted' Ingeniere. URL: http://www.univLehavre.fr/greah.

[51] Onar, O. C., Uzunoglu, M., Alam, M. S., "Dynamic modeling, design and simulation of a wind/fuel cell/ultra-capacitor-based hybrid power generation system." Journal of Power Sources. Vol. 161, No.1, 2006, pp. 707-722.

[52] Gupta, S. C., Kumar, Y., \& Agnihotri, G., "Optimal sizing of solar-Wind hybrid system." IETUK International Conference on Informat. and Communication Technology in Electrical Sciences, 2007,pp. 282-287.

[53] Wandhare, R. G., Agarwal, V., "A control strategy to reduce the effect of intermittent solar radiation and wind velocity in hybrid $\mathrm{PV} / \mathrm{Wind}$ SCIG system without losing MPPT."IEEE, 2011.

[54] Eshita, A., Yuvarajan, S., "Hybrid renewable energy system using DFIG and Multilevel Inverter." [Online], US Government work not protected by US copyright, Visited, Oct., 2013.

[55] Y. Sukamongkol, Y., Chungpaibulpatana, S., \& Ongsakul, W., "A simulation model for predicting the performance of a solar photovoltaic system with alternating current loads." Renewable Energy Vo. 27, No.2, Oct., 2002, pp.237-258.
[56] Nehrir, H., et. al, "A review of hybrid Renewable/alternative energy systems for electric power generation: configurations, control and applications", Power and Energy Society General Meeting 2012 IEEE.

[57] Banos, R., “Optimization methods applied to renewable and sustainable energy: A review."

Renewable and Sustainable Energy Reviews, Vol.15, No.4, May, 2010.pp.1753-1766.

[58] Ghaffarian, H., A. H., \& Dahlan, N. D., et. al. "Sustainable energy performances of green buildings: A review of current theories, implementations and challenges." Renewable and Sustainable Energy Reviews. Vol. 25, Sep., 2013, pp.1-17.

[59] Abedi, S., Alimardani, A., et.al. "Renewable and sustainable energy reviews." Vol.16 (2012) pp. 1577-1587. ELSEVIER.

[60] Nema, P., Nema, K. K., Rangneka, S., “A current and future state of art development of hybrid energy system using wind and PV-solar: A review." Renewable and Sustainable Energy Reviews, Vol.13, No.8, Oct., 2009, pp. 2096-2103.

[61] Deshmuk, M. M., \& Deshmukh, S. S., "Modeling of hybrid renewable energy systems." Renewable and Sustainable Energy Reviews. Vol.12, No.1, Jan., 2008, pp 235-249.

[62] Nwosu, C. A., Uchennna, U. C., \& T. C. Madueme, "Wind-Solar hybrid power system for rural applications in the South Eastern States of Nigeria." Journal of Electronics, Communication and Instrumentation Engineering Research, Vol. 2, No. 2, June 2012, pp.10-23.

[63] Abdel-Salam, M., Ahamed, A., et. Al, "Steady-state modelling and control of a microgrid supplying irrigation load in Toshka Area." IEEE, 2011, pp. 5689-5694.

[64] Erdinc, O., Vural, B., Uzunoglu, M., \& Ates, Y. "Modeling and analysis of an FC/UC hybrid vehicular power system using a wavelet-fuzzy logic based load sharing and control algorithm." International Journal of Hydrogen Energy, Vol. 34, No.12, Jun, 2009, pp. 5223- 5233.

[65] Delimustafic, D., Islambegovic, J., et. al "Model of a hybrid renewable energy system: control, supervision and energy distribution." IEEE, 2011, pp.1081-1086.

[66] Onar, O. C., Uzunoglu, M., \& Alam, M. S., "Modeling, control and simulation of an Autonomous wind turbine/photovoltaic/fuel cell/ultra-capacitor hybrid power system." Journal of Power Sources, Vol.185, No.2,Dec.,2008, pp,12731283. 
[67] Shiyas, P. R., Kumaravel, \& Ashok, S., "Fuzzy controlled dual input DC/DC converter for Solar-PV/Wind hybrid energy system." Students' conference on Electrical, Electronics \& computer Science, IEEE 2012.

[68] Safari, S., Ardehali, M. M., et. al. “Energy Conversion and Management." Vol. 65 pp. 41-49. 2013. ELSEVIER.

[69] Lalit, K., \& Jain, S., “A Multiple source DC/DC converter topology." International Journal of Electrical Power \&amp; Energy Systems, Vol. 51(2013) Oct., 2013, pp.278-291.

[70] Aissa, S., et. al. "Monitoring, modelling and simulation of PV systems using LabVIEW." Solar Energy, Vol. 91,(2013), pp. 337-349.

[71] Ahmed, N. A., Al-Othman, A. K., AlRashidi, M. R., "Development of an efficient utility interactive combined wind/photovoltaic/fuel cell power system with MPPT and DC bus voltage regulation" Electric Power Systems Research ,Vol. 81, No. 5, May, 2011, pp.1096-1106.

[72] Huang, Y., Xu, Y., Zhou, X., Study on WindSolar hybrid generating system control strategy. (2011) IEEE pp. 773-776.

[73] LI-Jifang, A., Tang, T., et. al. “A neural network control strategy for multi-energy common DC bus hybrid power supply." International Symposium on Power Electronics. SPEEDAM, IEEE, 2010.

[74] Lin, W. M., Hong, C. H., et.al. “NeuralNetwork-Based MPPT control of Stand-Alone hybrid power generation System." IEEE transactions on power electronics, VOL. 26, No. 12, Dec., 2011.

[75] Potamianakis, E. G., Vournas, C. D., "Modeling and simulation of small hybrid power systems." IEEE 2003: 0-7803-7967.

[76] Setiawan, A. A., Zhao, Y., \& Nayar, C. V., "Design, economic analysis and environmental considerations of mini-grid hybrid power system with reverse osmosis desalination plant for remote areas." Elsevier Renewable Energy 34(209) pp. 374383. ELSEVIER.

[77] Liang, W., Littler, T., "Modal Extraction for wind turbines using moving window subspace identification."International Conference on Sustainable Power Generation and Supply,2009 (SUPERGEN '09), pp. 1-9.

[78] Qi, W., J. Liu, X. Chen, P. D. Christofides, "Supervisory predictive control of standalone Wind/Solar energy generation systems." IEEE Transactions on control systems technology, Vol.19, No. 1, Jan., 2011, pp. 199-207.
[79] Qi, Y., Liu, X., “Wind-Photovoltaic-storage system optimal control scheme based on generation scheduling." e-mail: IEEE PES ISGT ASIA 2012, 1569534295.

[80] Mousavi, S. H., Fathi, S. H., et.al, "Energy management of Wind/Pv and battery hybrid system with consideration of memory effect in battery." IEEE.(2009) pp.630-633.

[81] Meenakshi, S., Rajambal, K., et.al "Intelligent controller for a stand- alone hybrid generation system." IEEE, 2006.

[82] Mtshali, T. R., Coppez, G., Chowdhury, S., "Simulation and modelling of PV-Wind-Battery hybrid power system." IEEE, 2011.

[83] Ekanayake, J., Holdsworth, Lee, Jenkins, N. "Control of DFIG wind turbines" Power Engineer Volume: 1 , Issue: 1 Publication Year: 2003, pp. $28-32$.

[84] Patsios, C., Antonakopoulos, M., \& Chaniotis, A., et.al "Control and Analysis of hybrid renewable energy-based power system." XIX International Conference on Electrical Machines, ICEM 2010, Rome.

[85] Liu, X., Wang, P., \& Loh, P. C. “A hybrid AC/DC Micro-Grid." IEEE,2010, pp. 746-751.

[86] Andrew, X. R. I., and, M., \& Sivakumar, P., "Modeling and analysis of emulator for Distributed generation sources smart grid using digital signal controller." (TMS 320F28335). 2011, IEEE, PES Innovative smart grid technologies-India.

[87] Kolhe, P., Bitzer, B., et. al, "Hybrid power system model and TELELAB." SWU, Germany and UCT, Research Project, South Africa.

[88] Jahdi, S., Lai, L. L., \& Nankoo, D., "Renewable hybrids Grid-Connection using converter interferences."International Journal of sustainable energy development (IJSED) Volume 1, 1-2 June 2012.

[89] Department of Energy \& Climate Change, UK [Online], "Energy Bill Summary Impact Assessment Report." Visited, 30th February 2013.

[90] Renewable obligation transition, "Impact Assessment Report-IA No:DECC0086," Department of Energy and Climate Change, UK. [Online] Visited: May 2013.

[91] Zahedi, A., “Technical analysis of electric power system consisting of solar PV energy, wind power and hydrogen fuel cell." Power Engineering Conference, AUPEC; 2007, pp.1-5. 
[92] Katti, P. K., et al, "Rural electrification through solar and wind hybrid system: A selfsustained grid free electric power source." ICAEE 2011, SciVerse Science Direct Energy Proc. 14 (2012), pp. 2081-2081.

[93] Sukamongkol, Y., et al, “A simulation model for predicting the performance of a solar photovoltaic system with alternating current loads." Renewable Energy, Vol. 27, No.2, October, 2002,pp.237-258.

[94] Kasera, J., et al. "Modeling and simulation of wind-PV hybridpower system using MATLAB/Simulink." Students' Conference on Elect. Elect. and Comp. Sci. 2012 IEEE.

[95] Dumitru, C. D., Gligor, A., "Modeling and simulation of renewable hybrid power system using MATLAB/Simulink Environment." Sci. Bull. of the, "Petru Maior" University of Targu Mures Vol.7 (XXIV) No.2, 2010.

[96] Teshale, A., "Modeling and simulation of intelligent hybrid power system. PhD Thesis, Lap Lambert Academic Publishing 2012.

[97] Wang, C., "Modeling and control hybrid wind/photovoltaic/fuel cell Distributed Generation Systems. PhD dissertation in Engineering, Montana State University, Bozeman, Montana, July, 2006.

[98] EPA, "Future Climate Change," United States Environmental Protection Agency Website, [Online], http://www.epa.gov/climatechange /science/future.html, Visited,15thMay2013.

[99] Lund, H., "Renewable energy strategies for sustainable development." Energy, Vol. 32 No.6 : 912-9, June, 2006.

[100] Ortjohann, E., “A simulation model for expandable hybrid power systems." University of Applied Sciences Sudwestfalen, Division Soest, Fachbereich 16-EU u. EW, Lubecker Ring 2, D-59494 Soest: ortjohann@fh-swf.de.

[101] Markel, T., Brooker, A., et. al. “ADVISOR: A systems analysis tool for advanced vehicle modeling." Elsevier J. Power Sources Vol.110, No.2, Aug. 2002 pp. 255-266.

[102] Huss, A., AKOMBE, Colongne, Germany: Wind power and hydrogen: complementary energy sources for sustainable energy supply. Fuel Cells Bulletin. April 2013.

[103] Elhadidy, E. A., \& Shaahid, S. M., "Promoting applications of hybrid (wind+photovoltaic+diesel+ battery) power systems in hot regions" Renewable Energy, Vol.29, No.4, Apr., 2004, pp. 517-528.

[104] Wijayatunga, D. C. P., \& Siriwardena, K., et.al. "Strategies to overcome barriers for cleaner generation technologies in small developing power systems: Sri Lanka case study." Energy Conversion and Management, Vol. 47, No.9-10, Jun., 2006, pp.1179-1191.

[105] Kaldellis, J. K., Zafirakis, D. P. “Trends, prospects and $\mathrm{R} \& \mathrm{D}$ directions of the global wind Energy sector." Lab of Soft Energy Applications \& Environmental Protection, TEI of Piraeus, P.O. Box 41046, Athens 12201, Greece e-mail: jkald@teipir.gr:[Online],http:/ / proceedings.ewea.or g/annual2012/allfiles2/ 1287_EWEA2012, Visited, 30thJune 2013.

[106] Johnson, V. H., “Battery performance models in ADVISOR." J. of Power Sources, Vol. 110, No.2, Aug., 2002, pp. 321-329.

[107] Zahedi, A., “Combination of renewable sources of energy and energy storage units for Providing a reliable power supply for remote and isolated areas." Proceedings of the $4^{\text {th International }}$ Conference on Advances in Power System Control, Operation and Management, APSCOM \& Hong Kong. IEE,1997, pp.559-562.

[108] Lajnef, T., Abid, S. \& Ammous, A., "Modeling, control and simulation of solar hybrid/fuel cell hybrid energy system for gridconnected applications." Hindawi Publishing Corporation Advances in Power Electronics Vol. 2013 article ID 352765.

[109] Traditional Windmill, [Online], http:/ / www.theenvironmentalblog. org/2009/03/ traditional-windmill., 2013, Visited, 27 th July, 2013.

[110] Breeze, A.J., "Next generation thin film solar cells." Solexant Corp. 2385 Bering Drive, San Jose, Ca 95131 IEEE 2008, e-mail: alison.breeze @solexant.com.

[111] Meier, J., et, al. "Potential of amorphous and microcrystalline silicon solar cells," Thin Solid Films, Vol. 451-452, Mar.,2004, pp. 518-524.

[112] Solarcell Efficiency, [Online], http://en.wikipedia.orgwiki/Solar_cell_efficiency, Visited, 6thJune 2013.

[113] Villalva, M. G., Gazoli, J. R.,\& Filho, E. R., "Comprehensive approach to modeling and simulation of photovoltaic arrays." IEEE Transactions on power electronics, Vol. 24, No.5, May, 2009, pp. 1198.

[114] Salmi, T., Bouzguenda, M., et.al. "MATLAB/Simulink Based Modelling of Solar photovoltaic Cell." International Journal of Renewable Energy Research, Vol.2, No.1, May 2012.

[115] El-Shafy, A., Nafeh, A., “Fuzzy Logic operation control for PV-Diesel-Battery hybrid energy system." The Open Renewable Energy Journal, 
Vol. 2, No.1, pp. 70-78. Electronics Research Institute, Cairo, Egypt. May 2009.

[116] University of St Andrews Sector(s): Energy \&Renewable., 2013, [Online], http://www. university-echnology.com/opportunity/121 /efficient-hydrogen-generation-for-Renewable -energy-storage-and-transmission. Visited, $1^{\text {th }}$ June 2013.

[117] Pozner, M., "Illustrated history of wind power development." Early History Through 1875 Translated from Ukranian.[Online],

http://telosnet.com/wind/early.html,Visited, 23 2 rd June 2013.

[118] Sklar, S., “Wind Turbines: Vertical Vs Horizontal Axis:" [Online], http://www.renewableenergyworld.com/rea/news /article/2006/10/wind-turbines-vertical-vshorizontal-axis-4629, Visited, 25th June 2013.

[119] The largest wind turbine in the world was installed in Germany.[Online], http:/ / www. windturbinestar.com/largest-wind-turbine.html, Visited, 29th June 2013.

[120] Hills, R. L., "History of Windmill Technology." $\quad$ Visited, http://books.google.co.uk/books? hl=en \& lr=\&id=FoVkfkBV1_8C\&oi, Visited,29th June 2013.

[121] Dolara, A., Faranda, R., \& Leva, S., “Energy comparison of seven MPPT techniques for PV systems," J Electromagn. Annual Appl., Sept., 2009, pp. 154-164.

[122] Kim, Y. H., Kim, S. S., "An electrical modeling and fuzzy logic control of a fuel cell generation system," IEEE Trans. Energy Convers. Vol. 14, No.2, June, 1999, pp. 239-244.

[123] Good Energy, Wind turbine FAQs,[Online], http://www.goodenergy.co.uk/generate/ choosingyour-technology/home-generation. Visited, 01st July, 2013.

[124] History of Windpower, [Online],http://en. wikipedia.org/wiki/Wind_turbine,Visited,01 stJuly, 2013.

[125] Wind speed and Wind Energy.[Online], http://energybible.com/wind_energy/ wind_speed.html, Visited, 01 st July, 2013.

[126] US Dept of Energy, [Online] Energy efficiency and renewable energy, Wind Program. Inside a wind Turbine, http:/ / www1.eere.energy. gov / wind, Visited, 02nd July 2013.

[127] Wind Power Program and UK Wind Speed Database programs, [Online], http://www. windpower-program.com/mean _power_calculation.htm, Visited, 1st July, 2013.
[128] Akdag, S. A., Guler, O., "Comparison of Wind Turbine Power Curve Models." International Renewable Energy Congress, Sousse, Tunisia: Istanbul Technical University, Energy Institute, Turkey. Nov. 2010.

[129] Treacy, M., "Caltech study says vertical axis wind turbines 10x more efficient than horizontalax is turbines." [Online], http://www.ecogeek.org/windpower/3555-caltech-study-says-vertical-axis-windturbines-10x.,Visited, 02 ${ }^{\text {nd }}$ July 2013.

[130] Hocaoglu, F.O., et al, “ The effect of model generated solar radiation data usage in hybrid (wind-PV) sizing studies." SciDir.Energy Conv. $\mathcal{E}$ Mana. Vol. 50, 2009, pp. 2956-2963.

[131] Types of Fuel Cells, [Online], http://www. fuelcells, org/base.cgim?template=types_of_fuel _cells, Visited, 10th July, 2013.

[132] Bludszuweit, H., Fandos, M., et. al, "Simulation of a hybrid system Wind Turbine Battery -Ultracapacitor ." CIRCE - ge3 - Department of Electrical Engineering, University of Zaragoza C /María de Luna 3, 50018 Zaragoza (Spain).

[133] Tammineedi, C., "Modeling battery-Ultra capacitor hybrid systems for solar and wind Applications." M Sc. Thesis in Energy and Mineral Eng. the PSU, The Grad.Sch. 2011.

[134] Rowe, A., Li, X., "Mathematical modeling of proton exchange membrane fuel cells."Journal of Power Sources, Vol. 102, No.1-2,Dec., 2001, pp.82-96.

[135] Mann, R. F., et.al "Development and application of a generalized steady-stateelectro chemical model for a PEM fuel cell." J. Power Sources,Vol.86, March, 2000.

[136] Pierucci, S., Ferraris, G.B., "Fundamental in Computational \& Numerical methods Software Architectures and Computing Frameworks for CAPE Parallel, Distributed and Grid Applications Large Scale Systems:" Algebraic, DAE, PDAE Nonlinear, Mixed-Integer, Stochastic Programming MultiObjective, Multiperiod, Global Optimization 20 th European Symposium on Computer Aided Process Engineering - ESCAPE20: 2010 Elsevier.

[137] Wang, C., Nehrir, H., et.al . "Dynamic Models and Model Validation for PEM Fuel Cells Using Electrical Circuits" IEEE Trans. on Energy Conv., Vol. 20, no. 2, June 2005.

[138] Pasricha, S., Steven, R., “A Dynamic PEM Fuel Cell Model."IEEE transactions on energy Conversion, Vol. 21, No. 2, June 2006.

[139] Bordall, C. R., García, C., et.al, “Dynamic model and simulations of a PEM fuel cell for residential applications." Hynergreen Technologies 
S.A.; Avda. de la Buhaira-Sevilla, Spain: Dept. of Elect. Eng.,University of Seville Camino de losDescubrimientos, s/n- ,

e-mail: cristina.rodriguez@hynergreen.abengoa.com

[140] Lee, J. M., Cho, B. H., “A Dynamic Model of a PEM Fuel Cell System."[Online], Available: Fuel Cell Vehicle Team, Hyundai Motor Company \& Kia Motors Corp: Korea. Department of Elect. Eng., Seoul National University, San 56-1, Silim-dong, Seoul, 151-742, Korea E-mail: jmoonyi@gmail.com. 2009 IEEE.

[141] Induction motors fed by PWM frequency inverters,[Online]http:/ / ecatalog.

weg.net/files/wegnet/WEG-induction-motors-fedby-pwm-frequency-converters-technical-guide -028-technical-article-english.pdf. Visited, $16^{\text {th }}$ July, 2013.

[142] World's Longest Wind Turbine Blades on Their Way to Scottish Offshore Test, http://www.offshorewind.biz/2013/07 /17/ worlds-longest-wind-turbine-blades-on-their-wayto-scottish-offshore-test-site/ Visited, 18 ${ }^{\text {th }}$ July 2013.

[143] The Netherlands Sets New Renewable Energy Targets.[Online], http://www.offshore wind. biz/2013/07/16/netherlands-sets-newrenewable-energy-targets/ Visited, 18 th July 2013.

[144] Australia: Carnegie Places Offshore Foundations Order for Wave Project, http://www.offshorewind.biz/2013/07/ 17/australia-carnegie-places-offshore-foundationsorder-for-wave-project/, Visited,18 th July, 2013.

[145] Japan: MODEC Develops Floating Wind \& Current Hybrid Power Generation System http://www.offshorewind.biz/2013/03/05/ japan-modec-develops-floating-wind-current hybrid-power-generation-system/,Visited, $18^{\text {th }}$ July, 2013.

[146] New-hybrid-technology-couldrevolutionise-green-sector.[Online], http://www.energylivenews.com /2013/06/05/new-hybrid-technology-couldrevolutionise-green-sector/ Visited, 18 th July, 2013.

[147] Herbert, B., Environmental Analyst, "Report from Intergovernmental Panel on Climate Change", IPCC Secretariat, SWITZERLAND, E-mail: IPCC-Sec@wmo.int. [Online], http://www.ipcc.ch, Visited, 23rduly, 2013.

[148] AlanWeber S., "Review of Sustainable and Renewable Energy Activities in the State of Qatar" IEEE 2013.

[149] Al Naser, W. E., Al Naser, N.W., "The Status of renewable energy in the GCC countries," Ren. and Sus. En. Rev., vol. 15, pp. 3078, 2011.
[150] Bachellerie, I. J., "Renewable Energy in the GCC Countries: Resources, Potential and Prospects." Dubai: Gulf Research Center, 2012, pp. 101.

[151] McCrone, A., et al., "Global Trends in Renewable Energy Investment 2011." Frankfurt, Germany: Frankfort School UNEP Centre and Bloomberg New Energy Finance, 2011, pp. 11.

[152] ANSYS Structural Analysis Guide, Chapter3 Modal Analysis, ANSYS, Inc. Southpointe 275 Technology Drive Canonsburg, PA 15317, http:/ / mostreal.sk/html/guide_55/g-str / gstr3.htm, Visited, 03rd Sept, 2013.

[153] Arulampalam1, A., Ramtharan, G., Jenkins, N., Ramachandaramurthy, V. K. , Ekanayake J.B. , Strbac, G., "Trends in wind power technology and grid code requirements". Second International Conference on Industrial and Information Systems, ICIIS 2007, 8 - 11 August 2007, Sri Lanka.

[154] Tennakoon, A. P., Ekanayake, J., Abeyratne, S., "Capability chart of a Doubly Fed Induction Generation based on its ratings and stability margin", Universities Power Engineering Conference (UPEC), 2010 45th International Publication Year: 2010 , pp. 1 - 5IEEE CONFERENCE PUBLICATIONS.

[155] Tennakoon, A. P., Arulampalam, A., Leite, H., Ekanayake, J. B., Abeyratna, S. G., “Operations of DFIG with simplified rotor current reference model and solution to the recent grid code requirements Industrial Electronics, 2009. IECON '09. 35th Annual Conference of IEEE.

[156] Ekanayake, J., Holdsworth, Lee., Jenkins, N. "Control of DFIG wind turbines" Power Engineer, Publication Year: 2003, pp.28 -32 